\title{
A Case Study of Chinese Mongolian Students in ELT under the Background of MOOCs
}

\author{
Lili Zhao ${ }^{1, *}$ \\ ${ }^{1}$ Department of Foreign Language Teaching, Inner Mongolia University for the Nationalities, Tongliao, China \\ *Correspondence: Department of Foreign Language Teaching, Inner Mongolia University for the Nationalities, \\ Tongliao, China. E-mail: lilingky@163.com
}

Received: November 30, 2015

Accepted: December 14, 2015 Online Published: December 19, 2015

doi:10.5430/wje.v5n6p108

URL: http://dx.doi.org/10.5430/wje.v5n6p108

\begin{abstract}
In response to the current reform of college English teaching, a case study of Chinese Mongolian students in English language teaching under the influence of MOOCs is carried out in an attempt to examine the efficacy of the integration of information technology into English language teaching.After a brief introduction of the teaching mode of MOOCs, this paper points out the constraints of the present English teaching, and then a case study of English language teaching following the principles of MOOCs is conducted with the purpose of finding out the appropriate teaching methods to motivate students. Through a careful design of the course, the relatively satisfactory teaching and learning outcomes are achieved.
\end{abstract}

Keywords: MOOCs; Course design; Learner-centered; Multimedia; Online system

\section{Introduction}

With the rapid development of information technology, a variety of teaching modes have sprung up in China, such as MOOCs, Flipped Class and network teaching. These newly emerging teaching modes have aroused great challenges to English teachers and they are in face of changing their teaching concepts, their teaching methods as well as their way of evaluating the students. In the past few years, it has been widely acknowledged that the development of information technology has changed the concept of education worldwide and researches concerning the integration of information technology into teaching have been made around the country. It is still a great concern for most teachers to take advantage of the web technology. A MOOC is a relatively recent online learning phenomenon, with the promotion of teaching reform, they are now generating considerable media attention and significant interest from higher education institutions. MOOCs carry the features of openness, fragmentation and generativity .There is a need for the change of teaching methods of students as well as the change of learning styles of students. It offers a way for teachers and students to share information with each other. This requires English teaching to be transformed from the aspects of teaching subjects, teaching content, teaching methods and teaching evaluation etc. By a careful analysis of the teaching objectives , the teaching content, and the teaching methods, the teacher carries out an empirical study under the background of MOOCs to figure out a way to incorporate advanced information technology into our traditional teaching with the purpose of enhancing the English teaching and learning process.

\section{Objectives of the Reform of English Language Teaching}

National Long-Term Education Reform and Development Plan Outline (2010-2020 years) clearly states "To strengthen the construction of education information infrastructure", "To strengthen the application of information technology" and etc. in which education informationization is placed in a very important position. In 2012, the National Ministry of Education further developed Education Informationization Development Plan for Ten Years (2011-2020), and emphasized "To promote information technology and higher education to be integrated deeply, to innovate talents training pattern" so as to push the Chinese education informationization to a new stage of development. It is thus clear that our nation has been aware the importance of education informationization for the development of Higher Education. In recent two years, with the development of MOOCs, the needs for reform of colleges become more urgent, and especially the reform of college class teaching mode has been imminent. Based on 
this kind of needs, this paper discusses in detail on reflection and reconstruction for college class teaching mode under MOOCs background.

\section{The Present Teaching Status of Chinese Mongolian Students}

Most of the Mongolian students in the university of Inner Mongolia are from rural mountain areas and because of the poor teaching conditions and the neglect of English teaching in local schools, students usually have a poor command of English and only a few students passed the college entrance examination. They are eager to learn English but they show little interest in the traditional teaching methods. In addition, in college English teaching, the quality of the education provision is highly variable, with many courses offering only recordings of lectures, and delivery is particularly difficult in some special fields that require practical classes, research projects or extensive library access. Besides, wider engagement with participants requires very considerable resource. Even limited feedback or examination becomes a major task if there are more than ninety students in the class. Therefore, MOOCs are well worthy of serious consideration for college teachers to meet the needs of students.

\section{The Definition of MOOC}

MOOC is the shortened form of massive open online course. It is an online course aimed at unlimited participation and open access via the web. It is a recent development in distance education which began to emerge in 2012.Many educators took advantage of the digital improvements for the purpose of teaching.(http://wenku.baidu.com).

MOOCs are the large-scale and open network online courses rising in recent two years with characteristics of openness, fragmentation and generativity, which is conducive to change the learning style of students and the teaching way of teachers to realize sharing of resources and to improve teaching quality. This requires the college class teaching should be transformed from the aspects of teaching subjects, teaching content, teaching methods and teaching evaluation etc. At present, a few international famous universities offer MOOCs to attract people who fail to afford the expensive costs of university education, or those who want to learn more knowledge though they have not enrolled in the course. The advantages that MOOCs provide are obvious. Universities with MOOCs can provide students with some most popular and valuable courses, and students can study at their own pace. It is a new way of online education. In MOOCs, students adopt an autonomous learning mode and they will feel free to conduct learning at their own pace and spend appropriate time in improving certain skills that they are not good at. The teaching mode of MOOCs is conducive to building social learning network, which contributes to the creation and sharing of knowledge. MOOCs have a profound impact on the promotion of open education.

\section{Teaching Constraints of Traditional Class}

Research continues to highlight the limited effect of teaching practice. Many problems exist in college English teaching. College class teaching form is single. Teachers manipulate the teaching process. The relationship between teachers and students is inharmonious. The teaching content is prepared in advance. The teaching method is inflexible. The teaching evaluation is unreasonable. In the traditional classroom, teachers focus mainly on two models of teaching, namely Grammar-translation, Audio-lingualism. As the names of some of its leading exponents suggest, Grammar Translation was the offspring of German scholarship, the object of which, according to one of its less charitable critics, was "to know everything about something rather than the thing itself." (Jack C. Richards \& Theodore S. Rodgers, 2000)

Learners often suffer from such tedious experiences of memorizing endless lists of grammar rules and vocabulary in an attempt to acquire a foreign language. Although the Grammar-Translation Methods often creates frustration for students, it makes few demands on teachers. It is still used in situations where understanding literary texts is the primary focus of foreign language study and there is little need for a speaking knowledge of the language. The English teaching at college usually use Grammar-Translation principles. Most of the students are language beginners and their English is poor. Grammar-Translation Method is the most commonly used way of the teaching mode. The teacher holds the idea that by analyzing the grammar and by finding equivalents between the students' language and the language to be learned, the students will know how the foreign language is constructed .During the grammar translation methods, much attention is paid to reading and writing rather than speaking ad listening and the sentence is the basic unit of teaching and language practice. The teacher transfers knowledge to students by a detailed analysis of the grammar rules, and a translation of sentences and texts into and out of the target language while Audio-lingualism is based heavily on behaviorist theories of learning. Audio-lingual class concentrates on long-repetition-drill stages. Its emphasis is on teaching the spoken language through dialogues and drills. This is to 
some extent suitable for language beginners to grasp the usage of language by repetition and imitation. In traditional English class of Chinese Mongolian students, the teacher employs many of the ingredients Audio-lingualism method: the use of short dialogues, the emphasis on spoken language, the value attached to practice, the emphasis on the students themselves speaking, the division into four skills, the importance of vocabulary control, the step-by-step progression, and so on.

\section{The Change of the Roles of Teachers and Learners in a Learner-centered Curriculum}

Teaching is fundamentally about working with people and about remaining alive to the many different things that go on when people hack their own path through the jungle towards new learning. An aware and sensitive teacher, who respects and listens to her students, and who concentrates on finding ways of enabling learning rather than on performing as a teacher, goes a long way to creating conditions in which a great deal of leaning is likely to take place. The difference between learner-centered and traditional curriculum development is that, in the former, the curriculum is a collaborative effort between teachers and learners, since learners are closely involved in the decision-making process regarding the content of the curriculum and how it is taught (Nunan, 2001). The teacher is no longer the central focus of the class. He serves as an instructor, organizer, counselor, and facilitator in the mode of MOOCs. The activities and the speaking are being done by everyone, rather than only by the person at the front of the room. Learners are not simply receiving passed-on wisdom, but are actively involved in their own learning. Just as Hedge states "In contributing to course design, Learners can research their needs, negotiate content, and help to monitor the progress of the course. In contributing to activity design, learners can explore and experiment. In developing more independent approaches, learners can plan, initiate, and organize their own work. And in a classroom where participation is high and its nature flexible, learners can question, clarify, suggest, and comment."(Hedge, 2002)

\section{A Case Study}

Chinese higher institutions as well as a growing number of secondary schools have been involved in engaging and experimenting with MOOCs for the purpose of exploring a new type of teaching mode and a different learning environment. MOOCs are gaining popularity in universities. Teachers intend to employ mixed teaching mode in their teaching process on the basis of the concept of MOOCs. According to constructing principles of university teaching, a hierarchical hybrid teaching mode is trying to be constructed. Specialized courses adopting mixed teaching mode is designed by "studying in the classroom is in the first and studying online is in the second". Public elective courses adopting mixed teaching mode is emphasized by "studying online is in the first and studying offline is in the second". General courses adopting mixed teaching mode is designed by the corporation of learning online and learning offline. In order to make a better teaching effect, the conditions such as the support of the university, technical support, the improvement of the teachers and students' information literacy as well as the joint work of the group teachers and the collaborative learning of the students are of utmost importance. The course design is made in the following steps.

\section{A. Teaching Materials}

In a learner-centered system, a range of materials which can be exploited in a variety of ways is more useful than a comprehensive package. "As the focus will be on assisting learners to do in class what they will need to be able to do outside, the materials should reflect the outside world. In other words, they should have a degree of authenticity." (Nunan, 2001). This authenticity should be related to the text sources as well as to student activities and tasks. The English lesson is chosen from forward English, Book one, Unit 6. The lesson contains five parts. They are dialogue, grammar, pattern practice, text and reading comprehension. The lesson lays emphasis on developing students' four skills to improve their communication abilities. The lesson is ready to begin with four parts. They are the analysis of the teaching program, the teaching materials, the teaching methods, the learning strategies, the teaching procedure, and the key points and difficult points of the lesson. The title of the text is "The Quarrel Between the Sun and the Wind". It is aiming at talking about fables that carry moral meanings. The main grammar rule is the degree of adjective and adverb. The teaching materials are selected according to the main topic of this unit. Similar fables like "The tortoise and the hare" that convey moral lessons are encouraged to be introduced by the students. In the lead-in part, the teacher uses pictures that describe some fables to let the students guess what these fables are, and then try to tell the fables in front of the whole class. It is proved to be of good effect for the teacher to offer the students the opportunity to take advantage of the objects in real life to make sentences using comparative structure.

\section{B. Teaching Objectives}

The teaching program of Forward English is designed based on the practical levels of students in the stage of vocational education. It emphasizes the cultural, implemental and practical functions of the course. It is a required 
basic course for undergraduate students. Under the guidance of theories of foreign language teaching, Forward English has its main knowledge and practical skills of the English language, learning strategies and intercultural communication. The objective of Forward English is to develop students' ability to use English in all -round way, especially in reading and speaking. And the objectives of this lesson contain three parts. They are the knowledge objects, ability objects, and moral objects.

1) knowledge objects, there are two aspects.

a. Enable the students to remember new words and phrases.

b. Get the students to be familiar with the sentence patterns

c. Enable the students to grasp the grammar rules

2) Ability objects

a. Ask the students to make a similar dialogue

b. Help them to understand the text better and improve the four skills of listening, speaking, reading and writing

c. Develop their ability of thinking independently

d. Enhance their ability to communicate with others easily

e. Cultivate their ability to discover, analyze and solve problems.

3) Moral objects

a. Get the students to know the implied meaning of fables

b. Arouse their interest in learning English

c. To encourage students to practice, participate and co-operate in the classroom activities.

\section{Teaching Methods}

Cummunicative approach, Toatal Physical Responses (TPR) method and computer-assisted instruction are to be used in the course of this lesson. As for the teaching activities, they should be organized according to the following principles.

a) awareness-raising activities about learning and the role of the learner

b) strategy training activities which encourage learners to be active in their learning

c) self-assessment activities(Hedge,2002)

During the lesson, emphasis are to be laid on:

a) learner-centered teaching

b) task-based learning

c) activity-based teaching(individual work, pair work ,group work, and class work)

d) collaborative learning

e) discussions in class

f) role play

g) independent learning

h) evaluation (teacher's evaluation and peer evaluation)

\section{Learning Methods}

a) Teach students how to be successful language learners

b) Teach students how to communicate with others, how to learn new words and how to learn independently

c) Get the students to form good learning habits.

d) Let students learn to settle problems by means of cooperation and discussion

\section{Implications for Education}

Under the teaching situation of MOOCs, a course design is made to build up students' interests and 
intercommunication ability. In such teaching background, the teacher must make a full preparation of the teaching materials before class and design the whole process of the classroom activities. Teachers use the online system to release information concerning teaching program and leaning tasks. In classroom, the teacher mainly lead the students to take part in class activities and make discussions about the important language points. Teachers often use multimedia to assist their teaching so that their teaching content can be rich and various. At the same time, vivid pictures, video and animation are used to arouse students' interest and enthusiasm so that students can engage themselves in the classroom activities. This helps students to acquire the knowledge of language, improve their ability to use language as well as enhance their critical thinking abilities. Research shows that students in such an environment can develop their potential learning abilities by means of finishing the teacher's task in class. The teachers' design of the classroom tasks can offer the students full play of their intellectual potential. Teachers may develop their own way of teaching procedures with a particular view of language and a particular theory of learning. They may frequently modify and change their teaching strategies in accordance to the learners' performance and their reactions to the teaching practice. Learners need the opportunity for both comprehensible input and output. Students can learn English online and offline. They use the online system to get a clear idea about the learning target, learning activities that they are going to participate in and the language focus they are going to learn. In the offline learning process, students are offered various kinds of activities to take part in. This method of foreign language learning not only stimulates students' agile thinking and their imagination but also their ability to express their ideas in English.

\section{Conclusion}

It is of vital importance to create as many links as possible between what happens in the classroom and what happens outside. Good lesson planning, and especially good specifying of objectives, does not therefore restrict you, but in clarifying the end point you intend to reach, sets you free to go towards that point in the most appreciate ways in class. In recent years, MOOCs(Massive Open Online Courses), as a new course mode, has become a focus in the education field both at home and abroad. Based on a review of the concepts and categories of MOOCs, this study attempts to illustrate the design and practice of MOOCs for English teaching and learning. The study is expected to promote the development of MOOCs for foreign language teaching and learning and with the use of online system and a variety of activities, students are highly motivated and they show great interest in English learning. This is conductive to students to be able to communicate effectively in their future studies and careers and at the same time enhance their ability to learn independently and improve their general cultural awareness so as to meet the needs of China's social development and international exchanges.

\section{References}

Hedge, T. (2002). Teaching and Learning in the Language Classroom. Shanghai, China: Shanghai Foreign Language Education Press. P103.

Hedge, T. (2002). Teaching and Learning in the Language Classroom. Shanghai, China: Shanghai Foreign Language Education Press. P36.

MOOCs. Retrieved from http://wenku.baidu.com

National Long-Term Education Reform and Development Plan. Retrieved from http://wenku.baidu.com

Nunan, D. (2001). The Learner-Centered Curriculum: A Study in Second Language Teaching. Shanghai, China: Shanghai Foreign Language Education Press. P99.

Nunan, D. (2001). The Learner-Centered Curriculum: A Study in Second Language Teaching. Shanghai, China: Shanghai Foreign Language Education Press. P2.

Richards, J.C., \& Rodgers, T.S. (2000). Approaches and Methods in Language Teaching. Beijing, China: Foreign Language Teaching and Research Press. 